\title{
Concentrations of selected heavy metals in Ligula intestinalis L., 1758 plerocercoids (Cestoda) compared to it host's (Tinca tinca L., 1758) organs from Beyşehir Lake (Turkey)
}

\author{
S. TEKIN-ÖZAN*1, M. BARLAS ${ }^{2}$ \\ ${ }^{1 *}$ Süleyman Demirel University, Faculty of Science and Art, Department of Biology \\ Isparta-TURKEY, E-mail: selda@fef.sdu.edu.tr; ${ }^{2}$ Muğla University, Faculty of Science and Art, \\ Department of Biology Muğla-TURKEY
}

\begin{abstract}
Summary
The accumulation of heavy metals ( $\mathrm{Cu}, \mathrm{Fe}, \mathrm{Zn}$ and $\mathrm{Mn}$ ) was measured by atomic absorption spectrophotometry in some organs of tench (Tinca tinca L., 1758) and tissues of its parasite collected from Beyşehir Lake, and compared with the data from sediments and water. The $\mathrm{Cu}$ levels in L. intestinalis L., 1758 plerocercoids were 1.69 times, respectively, higher than those in fish gill. $\mathrm{Zn}$ level in $L$. intestinalis plerocercoids was 2.13 times higher than those in fish liver, was 5.53 times higher than that of the muscle and 3.33 times higher than that in the gill. Significant negative (for $\mathrm{Mn}$ ) correlation was found between the quantity of heavy metals in water and tissues of L. intestinalis plerocercoids while there was significant negative (for $\mathrm{Cu}$ ) correlation between the quantity the heavy metals in bottom sediment and tissues of $L$. intestinalis plerocercoids. This study supports the idea that cestodes aren't very useful to determine the heavy metal pollution in aquatic system when they are located in their intermediate host's body cavity.
\end{abstract}

Key words: Ligula intestinalis; tench; parasite; heavy metals; pollution; Turkey

\section{Introduction}

Many animal species are found either in some eutrophic conditions like habitats with an anthropogenic effect or sylvatic conditions with low exposure to xenobiotic substances but both conditions don't affect the animals' together (Sures et al., 1997). Environmental conditions affect also aquatic hosts of parasites. Pollution may affect their health and cause extinction. These harmful changes are often associated with physiological reactions, which might be used as bioindicators (Segner, 1998; Segner \& Braunbeck, 1998).

Some researchers indicated that cestodes, nematodes and acanthocephalans are able to accumulate considerable concentrations of heavy metals (Tenora et al., 2000a; Baruš et al., 2001; 2007; Turčeková et al., 2002; Sures \& Siddall, 2003; Thielen et al., 2004; Tekin-Özan \& Kır, 2005; 2007; Retief et al., 2006; Genç et al., 2008). For example, mean concentrations of lead and cadmium in Monobothrium wageneri Nybelin, 1922 obtained from intestine of tench (Tinca tinca) were 75 and 40 times higher than in the muscle of host (Sures et al., 1997). Tenora et al. (2000a), investigated $\mathrm{Cr}, \mathrm{Pb}$ and $\mathrm{Cd}$ concentrations in the Ligula intestinalis L., 1758 plerocercoids and three of its intermediate hosts and they found that the $\mathrm{Pb}, \mathrm{Cr}$ and $\mathrm{Cd}$ levels in L. intestinalis plerocercoids were 15, 6 and 2.6 times higher than those in fish muscle. TekinÖzan and Kir (2005) reported that concentrations of $\mathrm{Cu}$, $\mathrm{Fe}, \mathrm{Zn}$ and $\mathrm{Mn}$ in Ligula intestinalis plerocercoids in the body cavity of tench (Tinca tinca) from Kovada Lake in Turkey were respectively $1.6-37.4$ times higher than in the muscle, liver and gill of the host and $2.2-691$ times higher than in the water. Cestodes therefore show a high capacity of bioaccumulation of heavy metals located in the intestine of their respective final host. This idea was supported by Baruš et al. (2000) who investigated $\mathrm{Cd}$ and $\mathrm{Pb}$ concentrations in L. intestinalis and its host Phalacrocorax carbo and found that $\mathrm{Cd}$ and $\mathrm{Pb}$ levels in parasite were higher than the host's tissues.

Ligula intestinalis (L., 1758) is a pseudophyllidean cestoda and a widespread and important pathogen of fish (Dubinina, 1980; Aydoğdu \& Öztürk, 2003). It has three hosts in its life cycle, the first intermediate host is a copepod, the second intermediate host is generally a cyprinid fish and the final host is a fish-eating bird (Dubinina, 1980; Ergönül \& Altındağ, 2005).

The aim of this study was to determine concentrations of 4 different metals in L. intestinalis plerocercoids and its fish host (Tinca tinca) from Lake Beyşehir, Turkey. Furthermore, element levels in Ligula intestinalis plerocercoids were also compared with sediment and water of Beyşehir 
Lake. The second aim was to indicate whether cestodes are more useful for accumulation bioindication of metals.

\section{Material and Methods:}

\section{Description of study area}

Beyşehir Lake (Fig. 1) is the largest freshwater lake in Turkey. The lake is located approximately $75 \mathrm{~km}$ from the city of Konya $\left(37^{\circ} 45^{\prime} \mathrm{N}, 31^{\circ} 30^{\prime} \mathrm{E}\right)$. It is used for irrigation and electrical energy production. The lake is approximately $50 \mathrm{~km}$ long, $15-20 \mathrm{~km}$ wide and $10 \mathrm{~m}$ deep. Its area and volume are about 65.000 ha and $5 \times 10^{8} \mathrm{~m}^{3}$, respectively (Tekin-Özan \& Kir, 2006).

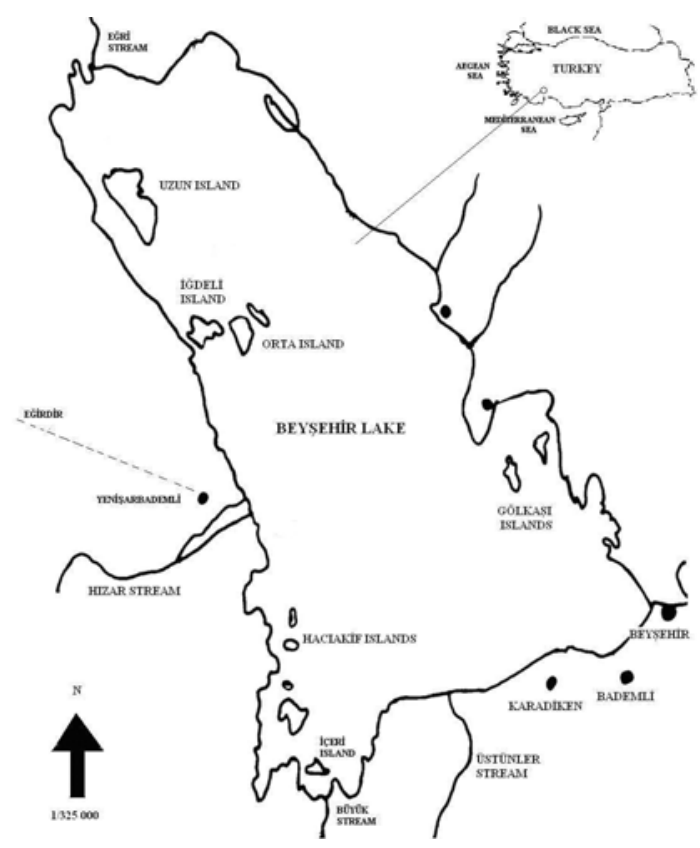

Fig. 1. Map of Beyşehir Lake (Turkey)

\section{Sampling}

A total of 40 tench (Tinca tinca L., 1758) were captured by fisherman in Beyşehir Lake. The sediments and water samples were also taken from Beyşehir Lake. The fish body weights were between $142-336 \mathrm{~g}$ and lengths were $21.5-29.6 \mathrm{~cm}$.

The samples were brought to the laboratory on the same day. The fish were killed by a blow on the head. The cestodes were collected separately from each body cavity of different fish. Approximately $4 \mathrm{~g}$ of the muscle on the surface of the fish, the entire liver and two gill racers from each fish were dissected, washed with distilled water, dried with filter paper, weighed, packed in polyethylene bags and kept at $-30^{\circ} \mathrm{C}$ until analysis.

\section{Analytical procedures}

Water samples were analyzed directly. The wet samples (tissues, sediment and cestoda) that were weighed (1 g) before, $5 \mathrm{ml}$ nitric acid (65\%) and $1 \mathrm{ml}$ hydrogen peroxide were placed into the digestion bombs and digested in a microwave digestion system. After digestion, the samples were cooled to room temperature. The resulting solutions were made up to exactly $25 \mathrm{ml}$ with high-quality deionized water and analyzed for $\mathrm{Cu}, \mathrm{Fe}, \mathrm{Zn}$ and $\mathrm{Mn}$ using a Perkin Elmer Atomic Absorpsion Spectrometer Analyst 800. The detection limit was $0.028 \mathrm{ppm}$ for all elements.

\section{Data analysis:}

Element concentrations in the tissues of tench, its parasites and sediment were determined as $\mathrm{mg}^{-\mathrm{kg}^{-1}}$ (wet weight) while water levels were determined as mg. $\mathrm{l}^{-1}$. Pearson correlation coefficient was used to test for significant associations between the data obtained from tench tissues, its parasites, water and sediment. Significant was accepted with $\mathrm{P} \leq 0.05$.

\section{Results}

The concentrations of heavy metals in fish tissues (liver, muscle and gill), L. intestinalis plerocercoids, water and sediment are summarized in Table $1 . \mathrm{Cu}, \mathrm{Fe}, \mathrm{Zn}$ and $\mathrm{Mn}$ were detected in water, sediment, $L$. intestinalis plerocercoids and different tissues of fish samples, while $\mathrm{Cu}$ was below detection limit $(<0.028 \mathrm{ppm})$ in muscle of tench and $\mathrm{Mn}$ in liver and muscle.

All elements analyzed were present at highest concentrations in liver, followed by gill and muscle $(<0.01)$. Only $\mathrm{Zn}$ was found to be significantly higher in the cestoda than in the liver and muscle, two $(\mathrm{Cu}$ and $\mathrm{Zn})$ higher than in the gill (Table 1).

Mean concentrations of copper in L. intestinalis was 1.69 times higher than that of the gill. The zinc level in L. intestinalis was 2.13 times higher than that of the liver, was 5.53 times higher than that of the muscle and 3.33 times higher than that in the gill. Fe levels in the parasite were below the levels in the liver $(\mathrm{P}<0.01)$, muscle and gill, but there were no significant differences $(\mathrm{P}>0.05)$ between the parasite and muscle and gill. Mn was also found to be higher amounts in the gill than in the parasite. The concentrations of Mn were also not significant $(>0.05)$ different between the parasite and the fish tissues.

Mean concentrations of $\mathrm{Cu}, \mathrm{Fe}, \mathrm{Zn}$ and $\mathrm{Mn}$ in L. intestinalis were 55.3, 6.38, 279 and 14.2 times higher than in the water (Table 1). Fe was recorded in the highest amount in water. Mn concentrations in L. intestinalis and gill of fish and $\mathrm{Zn}$ concentrations liver of fish different significantly from the water $(\mathrm{P}<0.05)$ (Table 2$)$. No significant association was found for $\mathrm{Cu}$ and $\mathrm{Fe}$ concentrations of water and the metal levels of host tissues and L. intestinalis (P > 0.05 ) (Table 2).

$\mathrm{Fe}$ was recorded in the highest amount in bottom sediments. Mean concentrations of $\mathrm{Zn}$ in L. intestinalis was 1.12 times higher than in the bottom sediments (Table 1). Positive (for $\mathrm{Fe}$ and $\mathrm{Zn}$ ) and negative $(\mathrm{Cu}$ and $\mathrm{Mn}$ ) correlations were detected between the content in L. intestinalis and their quantity in bottom sediments of their reservoir (Table 3). The $\mathrm{Cu}$ concentrations in L. intestinalis and $\mathrm{Fe}$ 
Table 1. Heavy metal concentrations in the liver, muscle, gill of fish (Tinca tinca L., 1758), Ligula intestinalis plerocercoids, water and bottom sediments

\begin{tabular}{|c|c|c|c|c|}
\hline Elements & $\mathrm{Cu}$ & $\mathbf{F e}$ & Zn & Mn \\
\hline $\begin{array}{l}\text { L. intestinalis } \\
\text { Range } \\
\text { Mean (mg/kg ww) } \\
\text { St. Dv. }\end{array}$ & $\begin{array}{l}1.19-9.57 \\
5.53 \\
2.60\end{array}$ & $\begin{array}{c}1.25-9.07 \\
4.34 \\
2.42\end{array}$ & $\begin{array}{c}23.47-68.79 \\
44.69 \\
11.92\end{array}$ & $\begin{array}{l}1.25-3.08 \\
2.14 \\
0.80\end{array}$ \\
\hline $\begin{array}{l}\text { Liver of fish } \\
\text { Range } \\
\text { Mean (mg/kg ww) } \\
\text { St. Dv. }\end{array}$ & $\begin{array}{c}8.86-28.53 \\
15.73 \\
6.29\end{array}$ & $\begin{array}{c}55.97-393.45 \\
162.42 \\
97.6\end{array}$ & $\begin{array}{c}13.46-26.82 \\
20.91 \\
4.38\end{array}$ & BDL \\
\hline $\begin{array}{l}\text { Muscle of fish } \\
\text { Range } \\
\text { Mean (mg/kg ww) } \\
\text { St. Dv. }\end{array}$ & BDL & $\begin{array}{l}3.26-9.49 \\
6.82 \\
2.21\end{array}$ & $\begin{array}{c}4.90-15.47 \\
8.07 \\
2.97\end{array}$ & BDL \\
\hline $\begin{array}{l}\text { Gill of fish } \\
\text { Range } \\
\text { Mean (mg/kg ww) } \\
\text { St. Dv. }\end{array}$ & $\begin{array}{l}2.39-4.57 \\
3.26 \\
0.97\end{array}$ & $\begin{array}{l}21.05-96.13 \\
50.62 \\
20.7\end{array}$ & $\begin{array}{c}10.40-19.09 \\
13.4 \\
2.61\end{array}$ & $\begin{array}{c}1.82-4.99 \\
3.74 \\
1.09\end{array}$ \\
\hline $\begin{array}{l}\text { Water } \\
\text { Range } \\
\text { Mean }(\mathrm{mg} / \mathrm{kg} \mathrm{ww}) \\
\text { St. Dv. }\end{array}$ & $\begin{array}{l}0.08-0.15 \\
0.10 \\
0.01\end{array}$ & $\begin{array}{c}0.10-2.74 \\
0.68 \\
0.94\end{array}$ & $\begin{array}{c}0.02-0.42 \\
0.16 \\
0.18\end{array}$ & $\begin{array}{l}0.02-0.52 \\
0.15 \\
0.24\end{array}$ \\
\hline $\begin{array}{l}\text { Sediment } \\
\text { Range } \\
\text { Mean (mg/kg ww) } \\
\text { St. Dv. }\end{array}$ & $\begin{array}{c}5.44-10.47 \\
7.16 \\
2.33\end{array}$ & $\begin{array}{c}3466-15136 \\
10397 \\
5263.03\end{array}$ & $\begin{array}{c}10.31-58.05 \\
39.82 \\
20.66\end{array}$ & $\begin{array}{c}57.65-1029.22 \\
484.19 \\
415.18 \\
\end{array}$ \\
\hline
\end{tabular}

ww, Wet weight; St.Dv., Standart deviation; BDL, Below Detection Limit

Table 2. Pearson correlation coefficient (r) and levels of significance determined for the relationship between the content of heavy metals in water, organs of fish and parasites

\begin{tabular}{cccccccc}
\hline $\mathrm{x}-\mathrm{y}$ & Metals & $\mathrm{r}$ & $\mathrm{P}$ & $\mathrm{x}-\mathrm{y}$ & Metals & $\mathrm{r}$ & $\mathrm{P}$ \\
\hline $\begin{array}{c}\text { Water-L.intestinalis } \\
(\mathrm{n}=24)\end{array}$ & $\mathrm{Cu}$ & 0.964 & $>0.05$ & Water-muscle of fish & $\mathrm{Cu}$ & - & - \\
& $\mathrm{Fe}$ & -0.086 & $>0.05$ & $(\mathrm{n}=24)$ & $\mathrm{Fe}$ & 0.334 & $>0.05$ \\
& $\mathrm{Zn}$ & 0.051 & $>0.05$ & & $\mathrm{Zn}$ & 0.011 & $>0.05$ \\
& $\mathrm{Mn}$ & -0.774 & $<0.05$ & & $\mathrm{Mn}$ & - & - \\
& & & & & & & \\
Water-liver of fish & $\mathrm{Cu}$ & 0.412 & $>0.05$ & Water-gill of fish & $\mathrm{Cu}$ & 0.740 & $>0.05$ \\
$(\mathrm{n}=24)$ & $\mathrm{Fe}$ & 0.600 & $>0.05$ & $(\mathrm{n}=24)$ & $\mathrm{Fe}$ & -0.340 & $>0.05$ \\
& $\mathrm{Zn}$ & 0.758 & $<0.05$ & & $\mathrm{Zn}$ & 0.497 & $>0.05$ \\
& $\mathrm{Mn}$ & - & - & & $\mathrm{Mn}$ & -0.836 & $<0.05$ \\
\hline
\end{tabular}

Table 3. Pearson correlation coefficient (r) and levels of significance determined for the relationship between the content of heavy metals in bottom sediments, organs of fish and parasites

\begin{tabular}{cccccccc}
\hline $\mathrm{x}-\mathrm{y}$ & Metals & $\mathrm{r}$ & $\mathrm{P}$ & $\mathrm{x}-\mathrm{y}$ & $\mathrm{Metals}$ & $\mathrm{r}$ & $\mathrm{P}$ \\
& & & & & & & \\
\hline $\begin{array}{c}\text { Sediment-L.intestinalis } \\
(\mathrm{n}=24)\end{array}$ & $\mathrm{Cu}$ & -0.635 & $<0.05$ & Sediment-muscle of fish & $\mathrm{Cu}$ & - & - \\
& $\mathrm{Fe}$ & 0.653 & $>0.05$ & $(\mathrm{n}=24)$ & $\mathrm{Fe}$ & 0.751 & $<0.05$ \\
& $\mathrm{Zn}$ & 0.167 & $>0.05$ & & $\mathrm{Zn}$ & -0.017 & $>0.05$ \\
& $\mathrm{Mn}$ & -0.015 & $>0.05$ & & $\mathrm{Mn}$ & - & - \\
& & & & & & & \\
\multirow{5}{S}{$\begin{array}{c}\text { Sediment-liver of fish } \\
(\mathrm{n}=24)\end{array}$} & $\mathrm{Cu}$ & 0.138 & $>0.05$ & Sediment-gill of fish & $\mathrm{Cu}$ & -0.035 & $>0.05$ \\
& $\mathrm{Fe}$ & -0.477 & $>0.05$ & $(\mathrm{n}=24)$ & $\mathrm{Fe}$ & 0.703 & $<0.05$ \\
& $\mathrm{Zn}$ & -0.440 & $>0.05$ & & $\mathrm{Zn}$ & -0.372 & $>0.05$ \\
& $\mathrm{Mn}$ & - & - & & $\mathrm{Mn}$ & -0.393 & $>0.05$ \\
\hline
\end{tabular}


concentrations in muscle and gill differed from the sediment $(\mathrm{P}<0.05)$ (Table 3).

\section{Discussion}

In this study, some heavy metal levels in water, sediment, Ligula intestinalis plerocercoids and its host tissues from Beyşehir Lake were measured.

All of the analyzed metals were determined in water and sediment. The highest metal in water and sediment was Fe. $\mathrm{Cu}, \mathrm{Fe}, \mathrm{Zn}$ and $\mathrm{Mn}$ levels in Ligula intestinalis plerocercoids were 55.3, 6.38, 279 and 14.2 times higher than the water. Compared to sediment, only $\mathrm{Zn}$ levels in Ligula intestinalis plerocercoids was 1.12 times higher than that in the sediment. Similar results were given by Tekin-Özan and Kır (2005) and Turčeková et al. (2002).

There are various investigations about accumulations of heavy metals in tapeworm's plerocercoids paraziting the body cavity of the fish intermediate host and birds as final hosts. Tekin-Özan and Kir (2005) found that the Fe level in Ligula intestinalis plerocercoid 37.4, 2.4 and 5.6 times higher than the muscle, liver and gill. Tenora et al. (2000a) investigated $\mathrm{Pb}, \mathrm{Cr}$ and $\mathrm{Cd}$ levels in Ligula intestinalis plerocercoids and found that $\mathrm{Pb}, \mathrm{Cr}$ and $\mathrm{Cd}$ concentrations in L. intestinalis plerocercoids are 15, 6 and 2.6 times higher than in the fish muscle. Similarly, Sures et al. (1997) reported that $\mathrm{Pb}$ and Cd levels in Monobothrium wageneri was 75 and 401 times higher than the muscle of its host. In contrast to these studies, Svobodová et al. (1996) found that Hg levels in Ligula intestinalis plerocercoids were lower than in muscles of roach. In this study, only $\mathrm{Zn}$ levels were higher than liver (2.13 times) and muscle (5.53 times). $\mathrm{Cu}$ and $\mathrm{Zn}$ levels were 1.69 and 3.33 times higher than gill, respectively. Conversely to Ligula intestinalis, acanthocephalans and nematodes accumulate heavy metals in high concentrations. The mean concentrations of $\mathrm{Fe}$ and $\mathrm{Zn}$ in Raphidascaris acus (Bloch, 1779) were 68.4 and 86.9 times higher than in the muscle of the host (Esox lucius) (Tekin-Özan \& Kır, 2007). Tenora et al. (2000a) reported that $\mathrm{Pb}, \mathrm{Cd}$ and $\mathrm{Cr}$ concentrations in Philometra ovata were 106.11, 119.09 and 43.52 times higher than host. Lead and cadmium levels in Pomphorhynchus laevis Müller, 1776 were 2700 and 400 times higher than in the muscle of the host (Sures et al., 1994a; Sures \& Taracshewski, 1995). Similar results were also reported for other fish species infected with acanthocephalans and nematodes (Sures et al., 1994b; Sures et al., 1997; Genç et al., 2008). Some researchers have investigated some heavy metal levels in Confluaria capillarioides, Mesocestoides perlatus and Ligula intestinalis and their final hosts (Podiceps cristatus, Accipiter gentilis and Phalacrocorax carbo) (Kráčmar et al., 2000; Tenora et al., 2000b; Baruš et al., 2000) and found that $\mathrm{Pb}$ and $\mathrm{Cd}$ levels in cestodes were higher than in hosts liver and muscle tissues. Sures et al. (1997) indicated that cestodes tend to accumulate high metals when they are located in the intestine of their final host. In the present study, some heavy metals levels in Ligula intestinalis ple- rocercoids were determined lower than the host tissues. This may be due to their larval stages and location in the body cavity of the intermediate host. Feeding strategy and age of the Ligula intestinalis plerocercoids affect the heavy metal accumulation in cestodes.

The results presented here demonstrate that cestodes obtained from fish hosts accumulate some heavy metals higher rates than the water but lower than some fish tissues and sediment. This study supports the idea that cestodes aren't very useful to determine the heavy metal pollution in aquatic system when they are located in their intermediate host's body cavity.

\section{Acknowledgements}

This work supported by TÜBİTAK, TBAG-AY/405 (105T008) project and Süleyman Demirel University, SDÜBAP-03-D-793 project. I would like to thank The Scientific and Technological Research Council of TurkeyBase Science Research Grant Group (TÜBİTAK-TBAG) and Süleyman Demirel University-Scientific Research Project Management (SDÜ-SDÜBAP) for their financial support. This study is a part of my doctoral thesis.

\section{References}

AYDOĞDU, A., ÖZTÜRK, M. O. (2003): Occurrence of Ligula intestinalis and Cucullanellus minutus in flounder, Platichthyes flesus L., in Dalyan Lagoon, (Karacabey, Bursa, Turkey) from September 1997 to June 1998. Bull. Eur. Ass. Fish. Pathol., 23 (6): 287 - 289

BARUŠ, V., JARKOVSKÝ, J., PROKEŠ, M. (2007): Philometra ovata (Nematoda: Philometroidea): a potential sentinel species of heavy metal accumulation. Parasitol. Res., 100: $929-933$

BARUŠ, V., TENORA, F., KRÀČMAR, S., HEDVÁBNy, J., PROKEŠ, M., SitKO, J. (2000): Heavy metals (Pb, Cd) concentrations in the Ligula intestinalis (Cestoda) and the host Phalacrocorax carbo (Aves). In Proc. $9^{\text {th }}$ Helminthol. Days, Dolni Věstonice, Czech Republic. Helminthologia, 37: $178-179$

BAruš, V., TenOra, F., KrÁČMAR, S., Prokeš, M. (2001): Accumulation of heavy metals in the Ligula intestinalis plerocercoids (Pseudophyllidea) of different age. Helminthologia, 38 (1): $29-33$

DubININA, M. N. (1980): Tapeworms (Cestoda, Ligulidae) of the fauna of the U.S.S.R. Amerind Publishing Co., New Delhi.

ERGÖNÜL, M. B., Altindă̆, A. (2005): The effects of Ligula intestinalis plerocercoids on the growth features of tench, Tinca tinca. Turk. J. Vet. Anim. Sci., 29: 1137 1341

Genc, E., Sangun, M. K., Durai, M., Can, F. M., Altunhan, C. (2008): Element concentrations in the swimbladder parasite Anguillicola crassus (nematoda) and its host the European eel, Anguilla anguilla from Asi River (Hatay-Turkey). Environ. Monit. Assess., (published online).

KráČMar, S., Tenora, F., Baruš, V., Hedvábný, J., 
SITKO, J. (2000): Accumulation of some heavy metals (Pb, $\mathrm{Cd}$ ) in Confluaria capillarioides (Cestoda) and the host Podiceps cristatus (Aves). In Proc. $9^{\text {th }}$ Helminthol. Days, Dolní Věstonice, Czech Republic. Helminthologia, 37:179

Retief, N. R., Avenant-Oldewage, A., Preez Du, H. (2006): The use of cestoda parasites from the largemouth yellowfish, Lebeobarbus kimberleyensis (Gilchrist and Thompson, 1913) in the Vaal Dam, South Africa as indicators of heavy metal bioaccumulation. Phys. Chem. Earth, 31: 840 - 847

SEGNER, H. (1998): Fish cell lines as a tool aquatic toxicology. In Braunbeck, T., Hinton, D. E., Streit, B. (Eds): Fish Ecotoxicoloy. Basel, Birkhäuser Verlag, $1-38$

SEGNER, H., BRAUnBECK, T. (1998): Cellular response profile to chemical stress. In SCHÜÜRMANN, G., MARKERT, B. (Eds): Ecotoxicology: Ecological Fundamentals, Chemical Exposure, and Biological Effects. New York, Wiley, 521 570

Sures, B., Siddall, R. (2003): Pomphorhynchus laevis (Palaeacanthocephala) in the intestine of chub (Leuciscus cephalus) as an indicator of metal pollution. Int. J. Parasitol., 33: $65-70$

SURES, B., TARASCHEWSKI, H. (1995): Cadmium concentrations of two adult acanthocephalans (Pomphorhynchus laevis, Acanthocephalus lucii) compared to their fish hosts and cadmium and lead levels in larvae of $A$. lucii compared to their crustacean host. Parasitol. Res., 81: $494-497$

Sures, B., TARASCHEWSKI, H., JACKWERTH E. (1994b): Comparative study of lead accumulation in different organs of perch (Perca fluviatilis) and its intestinal parasite Acanthocephalus lucii. Bull. Environ. Contam. Toxicol. 52: $269-273$

Sures, B., TARASCheWSKi, H., JACKWERTH, E. (1994a): Lead accumulation in Pomphorhynchus laevis and its host. J. Parasitol,. 80: 355 - 357

SuRES, B., TARASCHEWSKI, H., SidDALL, R. (1997): Heavy metals concentrations in adult acanthocephalans and cesto- des compared to their fish host and to established freeliving bioindicators. Parassitologia, 39: 213 - 218 Svobodová, Z., Groch, L., DrÁBeK, P., ModrÁ, H., Gelnar, M., KouBKovÁ, B. (1996): Biological and biochemical markers in fishes as indicators for $\mathrm{Mg}$ in environment. Project Vet. Pharm. Univ., Brno.

TEKIN-ÖZAN, S., KIR, İ. (2005). Comparative study on the accumulation of heavy metals in different organs of tench (Tinca tinca L. 1758) and plerocercoids of its endoparasite Ligula intestinalis. Parasitol Res., 97: 156 - 159

TEKIN-ÖZAN, S., KIR, İ. (2006). Concentrations of some heavy metals in organs of two fish species from the Beyşehir Lake, Turkey. Fresen. Environ. Bull., 15: 530 - 534

TEKIN-ÖZAN, S., KIR, İ. (2007): Accumulation of some heavy metals in Raphidascaris acus (Bloch, 1779) and its host (Esox lucius L., 1758). Acta Parasitol. Turcica, 31: $327-329$

TENORA, F., BARUŠ, V., KRÁČMAR, S., DrořÁČEK, J. (2000a): Concentration of some heavy metals in Ligula intestinalis plerocercoids (Cestoda) and Philometra ovata (Nematoda) compared to some their hosts (Osteichthyes). Helminthologia, 37: $15-18$

Tenora, F., Kráčmar, S., Baruš, V., HedvábnÝ, J., SitKo, J. (2000): Content of some heavy metals (Pb, Cd) in Mesocestoides perlatus (Cestoda) and the host Accipiter gentilis (Aves). In Proc. $9^{\text {th }}$ Helminthol. Days, Dolni Věstonice, Czech Republic. Helminthologia, 37: 179

THIElEN, F., ZimMERMANN, S., BASKA, F., TARASCHEWSKI, H., SURES, B. (2004): The intestinal parasite Pomphorhynchus laevis (Acanthocephala) from barbel as a indicator for metal pollution in the Danube River near Budapest, Hungary. Environ. Pollut.,129: 421 - 429

TURČEKOVÁ, L., HANZELOVÁ, V., ŠPAKULOVÁ, M. (2002): Concentration of Heavy Metals in Perch and Its Endoparasites in the Polluted Water Reservoir in Eastern Slovakia. Helminthologia, 39: $23-28$

ACCEPTED MARCH 5, 2008 